\title{
Changes in adipose tissue of the rat due to early undernutrition followed by rehabilitation
}

\author{
2. Strain differences and adipose tissue cellularity
}

\author{
BY PATRICIA M. HAR RIS* \\ Department of Medicine, Addenbrooke's Hospital, Hills Road, Cambridge CB2 $2 Q Q$
}

(Received 23 January 1979 - Accepted 4 June 1979)

\begin{abstract}
1. Male Wistar rats were allocated at birth to foster mothers in litters of three, nine or sixteen. At weaning animals from each litter size were ad lib.-fed on a stock diet. Further animals from litters of nine and sixteen were fed on the stock diet in restricted amounts until $\mathrm{I} 2$ weeks of age and then rehabilitated by being allowed ad lib. access to the stock diet.

2. Five animals from each group were killed at 24 weeks of age and the size and number of cells determined in four specific fat depots.

3. Animals reared in litters of sixteen and further undernourished from 3 to 12 weeks (group $L_{1} 6 / U$ ) had significantly fewer fat cells at all sites studied than animals reared in litters of three and ad lib.-fed. Group L16/U animals also had significantly fewer observable fat cells at the epididymal site than ad lib.-fed animals reared in litters of nine. These results differ from those found in the Black and White Hooded rat where, after similar treatments, no significant differences in observable fat cell number were found.
\end{abstract}

The results of Harris \& Widdowson (1978) and Harris (1980) suggest that early undernutrition of the Black and White Hooded rat did not cause a permanent change in either the observable fat cell number or the total fat cell number at any of the sites studied. This contradicts the results of previous workers (Knittle \& Hirsch, 1968) who had shown a significant change in fat cell numbers when undernutrition was commenced early in the life of the rat. The Black and White Hooded rat is a small, slow-growing strain compared with more frequently studied strains such as the Sprague-Dawley and the Wistar. It seems possible that the timing, speed and vulnerability of fat cell replication might not be the same for all strains of rat.

The present experiment was designed to follow the format of the investigation reported by Harris (I980). As far as possible the treatment of animals was identical except that Wistar rats were used instead of Black and White Hooded animals. Since the focus of interest was the long-term effects of undernutrition and rehabilitation, animals were studied only at the end of the experiment, when they were 24 weeks of age. The choice of 24 weeks of age was made as in previous work (Hirsch \& Han, I969; Johnson et al. I97 ; Harris \& Widdowson, I978; Harris, 1980) observable fat cell numbers appeared to have stabilized by this age in the rat. Only male rats were used since earlier investigations had shown no significant difference between males and females in their response to undernutrition (Harris \& Widdowson, 1978).

\section{MATERIALS AND METHODS}

Animals

Male Wistar rats were reared in the same manner as described by Harris (1980). Two mothers provided the $\mathrm{L}_{3} / \mathrm{C}$ animals; each suckled three, which were therefore well nourished before weaning, and they were ad lib.-fed after weaning. Two mothers each suckled nine males;

* Present address: Applied Biochemistry Division, DSIR, Palmerston North, New Zealand. 
from weaning at 3 weeks onwards four or five from each litter were ad lib.-fed $(\mathrm{Lg} / \mathrm{C})$ and the remainder undernourished from 3 to 12 weeks $(\mathrm{Lg} / \mathrm{U})$. Similarly two mothers each suckled sixteen males; eight from each litter were ad lib.-fed from weaning $\left(\mathrm{L}_{16} 6 / \mathrm{C}\right)$, and eight were undernourished from 3 to 12 weeks $\left(\mathrm{LI}_{16} / \mathrm{U}\right)$. The rats in groups $\mathrm{L}_{9} / \mathrm{U}$ and $\mathrm{L}_{16} / \mathrm{U}$ were ad lib.-fed from 12 to 24 weeks. All animals were killed at 24 weeks and adipose tissue was removed from the abdominal, scapular, perirenal and epididymal sites as described by Harris (1980). Samples were divided in two, weighed, and one part immersed in formol saline ( $9 \mathrm{~g}$ sodium chloride/l) for the determination of mean cell size, and the other part was immersed in diethyl ether for the determination of total triglyceride.

\section{Techniques}

Size of fat cells, determinations of triglyceride and numbers of apparent fat cells were carried out as described by Harris ( 1980 ).

\section{RESULTS}

Fig. I shows the live-weight curves of each group of animals. There was little difference in weaning weight between animals reared in litters of three and those reared in litters of nine. However, the animals reared in litters of sixteen were significantly smaller than those from litters of three and nine. This trend continued throughout the experiment and is in contrast to the growth curves of the Black and White Hooded rats, which displayed a closer similarity between animals reared in litters of nine and those reared in litters of sixteen rather than litters of three and litters of nine. Wistar rats reared in the groups $\mathrm{L}_{3} / \mathrm{C}, \mathrm{L} 9 / \mathrm{C}$ and $\mathrm{L}_{1} 6 / \mathrm{C}$ attained heavier body-weights than the Black and White Hooded rats reared in the corresponding groups. They also had a greater rate of weight gain early in life $(7 \mathrm{~g} / \mathrm{d}$ maximum for the Wistars and $5 \mathrm{~g} / \mathrm{d}$ maximum for the Black and White Hooded rats).

Table I shows the weights of adipose tissue at each site sampled in each group. Rather unexpectediy the ad lib.-fed animals reared in litters of nine consistently had more adipose tissue at every site than $a d$. lib.-fed animals reared in litters of three. Animals undernourished from birth to 12 weeks of age and rehabilitated (group LI6/U) had significantly less adipose tissue than ad lib.-fed animals reared in litters of three or nine. Approximately the same weights of adipose tissue were present at each site as were present in the equivalent Black and White Hooded group at the same age, although the Wistar animals were heavier. There was a tendency for the Wistar animals to have less subcutaneous fat than the ad lib.fed Black and White Hooded animals.

Table 2 shows the volumes of apparent fat cells at each site sampled in each group. There was no significant difference in mean cell volumes between any of the groups. The animals reared in litters of nine tended to have larger cell volumes than those reared in litters of three. All cell volumes were significantly smaller than those at the same sites in the equivalent Black and White Hooded rats.

Table 3 shows the number of apparent fat cells at each site sampled in each group. Animals undernourished from birth to 12 weeks of age had significantly fewer cells at every site compared with ad lib.fed animals reared in litters of three. Animals from litters of nine undernourished from 3 to 12 weeks had significantly fewer apparent cells compared with ad lib.-fed animals reared in litters of three only at the perirenal site. There was no significant difference in apparent cell numbers between animals undernourished and rehabilitated and ad lib.-fed animals of the same litter size. Animals undernourished from birth to 12 weeks of age had significantly fewer apparent fat cells at the scapular and epididymal sites than did animals reared in litters of nine and ad lib.-fed. 


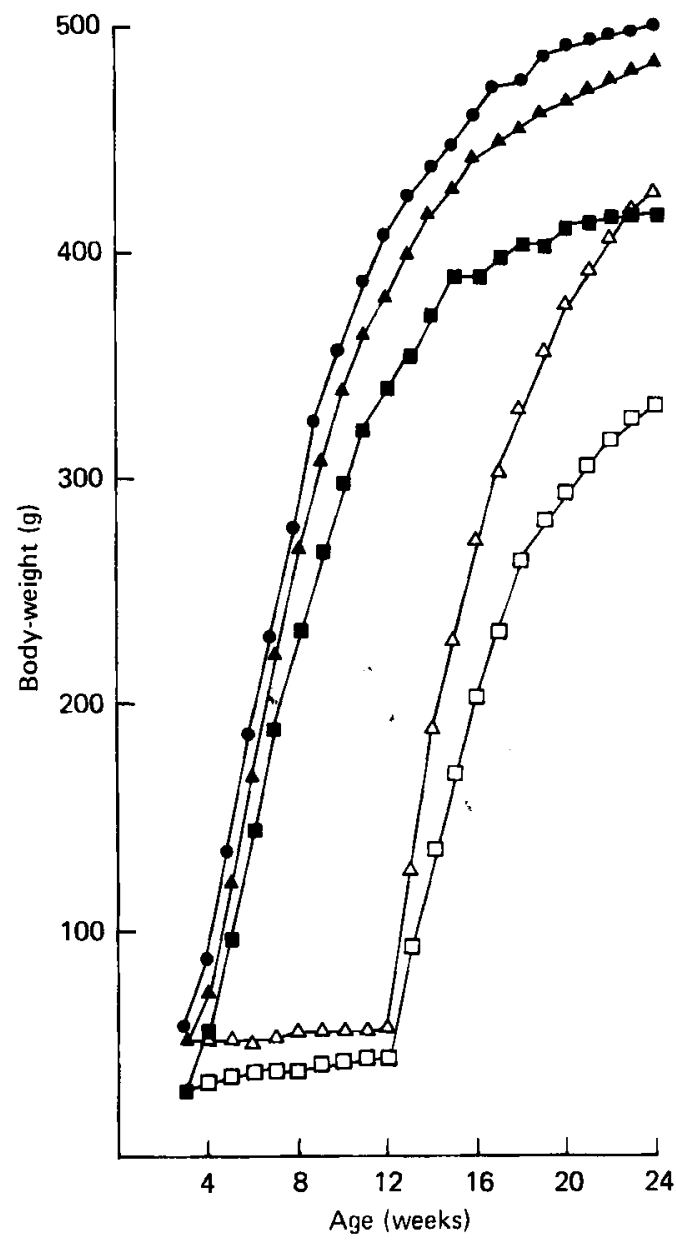

Fig. 1. Growth curves of ad lib.-fed and undernourished-rehabilitated rats (for details of feeding regimen see p. 28). Animals from litters of three, ad lib.-fed from weaning; $\mathbf{A}$, animals from litters of nine, ad lib.-fed from weaning; $\square$, animals from litters of sixteen, ad lib.-fed from weaning; $\triangle$, animals from litters of nine, undernourished from 3 to 12 weeks; $\square$, animals from litters of sixteen, undernourished from 3 to 12 weeks.

Table I. Weights $(\mathrm{mg})$ of adipose tissue at all sites sampled in groups of Wistar rats from litters of three, nine or sixteen fed on the control diet (groups $L_{3} / C, L 9 / C$ and $L_{1} 6 / C$ respectively) or litters of nine and sixteen undernourished $\left(L 9 / U\right.$ and $L_{1} 6 / U$ respectively)*

(Mean values with their standard errors for five animals)

\begin{tabular}{|c|c|c|c|c|c|c|c|c|c|c|}
\hline \multirow{2}{*}{$\begin{array}{l}\text { Group ... } \\
\text { Site }\end{array}$} & \multicolumn{2}{|c|}{$\mathrm{L}_{3} / \mathrm{C}$} & \multicolumn{2}{|c|}{$\mathrm{Lg} / \mathrm{C}$} & \multicolumn{2}{|c|}{ Li6/C } & \multicolumn{2}{|c|}{$\mathrm{Lg} / \mathrm{U}$} & \multicolumn{2}{|c|}{ Li6/U } \\
\hline & Mean & SE & Mean & SE & Mean & SE & Mean & $\mathrm{SE}$ & Mean & SE \\
\hline Abdominal & 7090 & 440 & 8930 & 1230 & 5590 & 590 & $\begin{array}{l}6270 \\
1670\end{array}$ & $\begin{array}{r}210 \\
80\end{array}$ & $\begin{array}{l}4780 \\
1370\end{array}$ & $\begin{array}{l}540 \\
160\end{array}$ \\
\hline $\begin{array}{l}\text { Scapular } \\
\text { Perirenal }\end{array}$ & $\begin{array}{l}1740 \\
6160\end{array}$ & $\begin{array}{l}290 \\
540\end{array}$ & 9030 & 1300 & 5120 & 1150 & 4780 & 310 & 3900 & 540 \\
\hline Epididymal & 6750 & 470 & 10320 & 1200 & 5750 & 990 & 6570 & Ino & 3850 & 530 \\
\hline
\end{tabular}

* For details of feeding regimens, see p. 28. 
Table 2. Volumes $\left(\mu m^{3}\left(\times \mathrm{IO}^{3}\right)\right)$ of apparent cells at all sites sampled in groups of Wistar rats from litters of three, nine or sixteen fed on the control diet (groups $L 3 / C, L 9 / C$ and $L I 6 / C$ respectively) or litters of nine and sixteen undernourished $(L 9 / U$ and $L 16 / U$ respectively)*

(Mean values with their standard errors for five animals)

\begin{tabular}{|c|c|c|c|c|c|c|c|c|c|c|}
\hline \multirow{2}{*}{$\begin{array}{l}\text { Group ... } \\
\text { Site }\end{array}$} & \multicolumn{2}{|c|}{$\mathrm{L}_{3} / \mathrm{C}$} & \multicolumn{2}{|c|}{$\mathrm{L} g / \mathrm{C}$} & \multicolumn{2}{|c|}{$\mathrm{Li6} / \mathrm{C}$} & \multicolumn{2}{|c|}{$\mathrm{L} 9 / \mathrm{U}$} & \multicolumn{2}{|c|}{$\mathrm{LI6/U}$} \\
\hline & Mean & $\mathbf{S E}$ & Mean & SE & Mean & SE & Mean & SE & Mean & $\mathbf{S E}$ \\
\hline Abdominal & 339 & 15 & 428 & 94 & 252 & 68 & 373 & 9 & 337 & 66 \\
\hline Scapular & 159 & 24 & 227 & 58 & 197 & 47 & 215 & 24 & 200 & 13 \\
\hline Perirenal & 384 & 61 & 895 & 200 & 549 & 142 & 587 & 136 & 431 & 23 \\
\hline Epididymal & 417 & 57 & 691 & 222 & 470 & 89 & 623 & I15 & 325 & 46 \\
\hline
\end{tabular}

Table 3. Numbers $\left(\times 10^{5}\right)$ of apparent cells at all sites sampled in groups of Wistar rats from litters of three, nine or sixteen fed on the control diet (groups $L_{3} / C, L 9 / C$ and $L_{16} / C$ respectively) or litters of nine and sixteen undernourished $(L 9 / U$ and $L 16 / U$ respectively)*

(Mean values with their standard errors for five animals)

\begin{tabular}{|c|c|c|c|c|c|c|c|c|c|c|}
\hline \multirow{2}{*}{$\begin{array}{l}\text { Group ... } \\
\text { Site }\end{array}$} & \multicolumn{2}{|c|}{$\mathrm{L}_{3} / \mathrm{C}$} & \multicolumn{2}{|c|}{$\mathrm{L} g / \mathrm{C}$} & \multicolumn{2}{|c|}{$\mathrm{L} 16 / \mathrm{C}$} & \multicolumn{2}{|c|}{$\mathrm{L} 9 / \mathrm{U}$} & \multicolumn{2}{|c|}{$\mathrm{Li6/U}$} \\
\hline & Mean & SE & Mean & SE & Mean & $\mathrm{SE}$ & Mean & $\mathbf{S E}$ & Mean & SE \\
\hline Abdominal & 213 & 39 & 133 & $2 \mathrm{I}$ & 132 & 26 & 134 & 10 & 115 & 17 \\
\hline Scapular & 76 & 14 & 85 & 14 & 66 & 22 & 58 & 4 & 44 & 6 \\
\hline Perirenal & 169 & 20 & 109 & I4 & 91 & 8 & 98 & 14 & 85 & 9 \\
\hline Epididymal & 145 & 10 & 143 & II & 118 & 12 & 123 & 4 & 100 & 10 \\
\hline
\end{tabular}

\section{DISCUSSION}

The major result from this experiment was that undernutrition from birth to 12 weeks followed by rehabilitation caused a change in apparent fat cell numbers in the Wistar strain at 24 weeks compared with ad lib.-fed rats from litters of three. Further, undernutrition from birth to 12 weeks caused a difference in apparent fat cell numbers at the epididymal site compared with those in ad lib.-fed rats from litters of nine. These results confirm the changes in the apparent number of fat cells at the epididymal fat pad reported by other workers and suggest that they only occur in fast-growing strains of rat which, presumably, have a greater sensitivity to nutritional manipulation. As these differences cannot be shown in the slower-growing strain of rat it seems possible that there are major strain differences in either the timing of the replication period or the speed of replication, or both.

The author would like to thank Dr E. M. Widdowson for her generous help in the preparation of this paper. The work was carried out while the author was supported by a Sir Walter Mulholland Fellowship. 


\section{REFERENCES}

Harris, P. M. (1980). Br. J. Nutr. 43, 15.

Harris, P. M. \& Widdowson, E. M. (1978). Br. J. Nutr. 39, 201.

Hirsch, J. \& Han, P. W. (1969). J. Lipid Res., Io, 77.

Johnson, P. R., Zucker, L. M., Cruce, J. A. F. \& Hirsch, J. (197I). J. Lipid Res. 12, 706.

Knittle, J. L. \& Hirsch, J. (I968). J. clin. Invest. 47, 2091. 